\title{
International Legal Accountability Through the Lens of the Law of State Responsibility
}

\author{
Jutta Brunnée
}

\author{
Version Publisher's Version
}

Citation Brunnée, Jutta, International Legal Accountability Through the Lens of (published version) the Law of State Responsibility (2005). Netherlands Yearbook of International Law, Vol. 36, pp. 3-38, 2005.

Publisher's Statement Brunnée, Jutta, International Legal Accountability Through the Lens of the Law of State Responsibility (2005). Netherlands Yearbook of International Law, Vol. 36, pp. 3-38, 2005.

Copyright (C) [2005]. Reprinted by permission of the Netherlands Yearbook of International Law. The final form of this article can be found at https://doi.org/10.1017/s0167676805000218

\section{How to cite TSpace items}

Always cite the published version, so the author(s) will receive recognition through services that track citation counts, e.g. Scopus. If you need to cite the page number of the author manuscript from TSpace because you cannot access the published version, then cite the TSpace version in addition to the published version using the permanent URI (handle) found on the record page.

This article was made openly accessible by $U$ of $T$ Faculty. Please tell us how this access benefits you. Your story matters. 
INTERNATIONAL LEGAL ACCOUNTABILITY THROUGH THE LENS OF THE LAW OF STATE RESPONSIBILITY*

\section{Jutta Brunnée**}

1. Introduction

2. International legal accountability through state responsibility

$2.1 \quad$ Primary rules

2.2 Secondary rules

2.2.1 Breaches of international law - the reach of the state responsibility regime

2.2.2 Wrongful acts by, or attributable, to states - what are states accountable for?

2.2.3 Invocation of responsibility - to whom are states accountable?

2.2.4 Legal consequences of internationally wrongful acts and available remedies

2.2.4.1 Countermeasures

3. Alternative modes of international legal accountability

3.1 Primary rules

3.1.1 Non-state actors

3.1.2 Collective or community concerns

3.1.3 Norm texture

3.2 Secondary rules

3.2.1 From responsibility to liability

3.2.2 Non-state actors

3.2.2.1 Accountability of non-state actors

3.2.3 Inter-state accountability

* C) J. Brunnée, 2006

** Professor of Law and Metcalf Chair in Environmental Law, Faculty of Law, University of Toronto. I am grateful for the excellent research assistance provided by Kate Brookson-Morris. I also wish to thank Marcel Brus and the participants in the Seminar on Accountability in the International Legal Order, held in Amsterdam, 24 February 2006, for their very helpful comments on an earlier draft of this article. 
4. Conclusion

Abstract

\section{INTRODUCTION}

Understood in the broadest sense, 'accountability' involves the justification of an actor's performance vis-à-vis others, the assessment or judgment of that performance against certain standards, and the possible imposition of consequences if the actor fails to live up to applicable standards. ${ }^{1}$ Accountability questions arise where an actor exercises particular functions, powers or authority. They can be political, administrative, financial or legal in nature. ${ }^{2}$ A wide range of accountability questions is now being raised in the international legal arena, ${ }^{3}$ including in the present volume. Notwithstanding its increasingly frequent invocation by international lawyers, the concept of 'accountability' has not acquired a clearly defined legal meaning. ${ }^{4}$ It is safe to say, however, that the concept of international legal 'responsibility' denotes a particular form of legal accountability, focused upon the legal consequences of breaches of international law that are attributable to an international actor. ${ }^{5}$

1. See R.W. Grant and R.O. Keohane, 'Accountability and Abuses of Power in World Politics', 99 American Political Science Review (2005) p. 29 at pp. 29-30.

2. See International Law Association (ILA), 'Accountability of International Organisations', Report of the Seventy-First Conference, Berlin 2004 (London, ILA 2004) p. 164 at p. 168.

3. See e.g., M. Newton, 'The Bush Administration View of International Accountability (Responding to Rogue Regimes from Smart Bombs to Smart Sanctions)', 36 New England LR (2002) p. 891; L. Boisson de Chazournes, 'Accountability, Rule of Law and ICJ Advisory Opinions', in W.P. Heere, ed., From Government to Governance: The Growing Impact of Non-State Actors on the International and European Legal System (The Hague, T.M.C. Asser Press 2003) p. 77; B. Stephens, 'Accountability for International Crimes: the Synergy between the International Criminal Court and Alternative Remedies', 21 Wisconsin ILJ (2003) p. 527; (Panel Discussion) 'The International Responses to the Environmental Impacts of War: Afternoon Panel - Accountability and Liability: Legal Tools Available to the International Community', 17 Georgetown IELR (2005) p. 616; V. Nanda, 'Accountability of International Organizations: Some Observations', 33 Denver JIL \& Pol. (2005) p. 379.

4. Indeed, in several languages, including French, German, Spanish and Russian, even the term 'accountability' finds no direct equivalent. See G. Hafner, 'Accountability of International Organizations', in American Society of International Law (ASIL), Proceedings of the 97th Annual Meeting (2003) p. 236 at p. 236.

5. But see also A. Nollkaemper, 'Responsibility of transnational corporations international environmental law: three perspectives', in G. Winter, ed., Multilevel Governance of Global Environmental Change: Perspectives from Science, Sociology and the Law (Cambridge, Cambridge University Press 2006) p. 179 at pp. 181-182 (on the different usages of the term 'responsibility' in international law). 
In its origins, the regime of international legal responsibility was a highly limited one. It was confined to injuries inflicted by states on aliens or their property, which were conceptualized as injuries to the alien's home state. ${ }^{6}$ Progressively, the rules of state responsibility evolved into a general regime for determining the consequences of states' breaches of international law and the circumstances under which other states can invoke such breaches. It is to this general regime that the International Law Commission (ILC) devoted the bulk of its efforts to codify and develop the law of international responsibility. ${ }^{7}$ State responsibility remains the 'paradigm form of responsibility on the international plane'. ${ }^{8}$ Given the focus of classical international law upon the rights and obligations of states, its enduring conceptual centrality is hardly surprising. Nor are its inherent limitations in facilitating international legal accountability. By definition, the regime can facilitate only inter-state accountability on the basis of positive legal rules. It is for this very reason that it provides a useful analytical tool. ${ }^{9}$ The regime at once reflects a particular vision of international law and reveals the partial nature of that image. This article therefore examines questions of accountability in the international legal system through the lens of the state responsibility regime.

It begins with an examination of the law of state responsibility and of the contours of the accountability framework that it provides. This assessment covers both the constraints inherent in the primary rules the breach of which may give rise to responsibility, and the limitations that flow from the secondary rules that govern such breaches. Primary rules, in the conception of the ILC, are not part of the law of state responsibility proper. ${ }^{10}$ Rather, the latter encompasses only the secondary rules that are triggered by the breach of a primary rule, and that define the consequences of such an internationally wrongful act. ${ }^{11}$ Nonetheless, to understand the extent to which the state responsibility regime can facilitate accountability, both primary and secondary rules must be considered.

6. See D. Bodansky and J. Crook, 'Symposium: The ILC's State Responsibility Articles - Introduction and Overview', 96 AJIL (2002) p. 773 at p. 776.

7. After a short-lived initial focus upon responsibility for injury to aliens. See J. Crawford, The International Law Commission's Articles on State Responsibility; Introduction, Text and Commentaries (Cambridge, Cambridge University Press 2002) p. 2.

8. J. Crawford and S. Olleson, 'The Nature and Forms of International Responsibility', in M. D. Evans, ed., International Law (Oxford, Oxford University Press 2003) p. 445 at p. 446.

9. See also D. Bederman, 'Counterintuiting Countermeasures', 96 AJIL (2002) p. 817 (observing that the state responsibility regime goes 'to the intellectual core of public international law by delimiting the character of states and the nature of their obligations when they interact with other international actors'.).

10. See J. Crawford, 'The ILC's Articles on Responsibility of States for Internationally Wrongful Acts: A Retrospect', 96 AJIL (2002) p. 874 at pp. 876-879.

11. Arts. 1 and 2, Draft Articles on Responsibility of States for Internationally Wrongful Acts, in ILC, Report of the International Law Commission on the Work of Its Fifty-third Session, UN GAOR, 56th Sess., Supp. No. 10, p. 43, UN Doc. A/56/10 (2001) [hereinafter ILC Draft Articles]. 
The article then turns to the increasingly rich variety of other modes of international legal accountability. Arguably, the rise of these alternative modes is a reaction both to the limits of the conceptual structure that anchors the state responsibility regime and to the fact that states only rarely take the formal step of invoking it. By the same token, it is a reflection of the fact that the traditional conception of international law as a set of inter-state rules flowing from certain formal sources is no longer a sufficient account of international legal relations. Conceptually, international law expresses collective concerns in addition to the mutual rights and obligations of states. It also engages the legal interests of other international actors, including individuals, international organizations, and corporations. In terms of legal processes, states and other international actors rely upon increasingly diverse modes of law-making and implementation, including various types of 'soft' legal techniques. International environmental law and international human rights law are paradigmatic for the expansion of international law's normative horizons beyond inter-state concerns, the widening of the range of actors, and the diversification of legal methods. It is therefore primarily from these areas that examples will be drawn in this article

This evolution of international law leads back to the general definition of accountability that was offered in the opening sentence of this article. With some adjustments, this definition provides a useful framework for the purposes of international law. International legal accountability, then, involves the legal justification of an international actor's performance vis-à-vis others, the assessment or judgment of that performance against international legal standards, and the possible imposition of consequences if the actor fails to live up to applicable legal standards. This definition is helpful precisely because it is open-ended in a number of ways: it does not focus on a closed category of actor; it does not tie the category of legal standard exclusively to a canon of formal sources; and it does not predetermine the processes through which legal justification, assessment, judgment or imposition of consequences can be undertaken. The definition is helpful, therefore, because it accommodates both the fundamental transformations that the international legal order has been undergoing and the increasingly rich variety of modes of international legal accountability.

Of course, this more open-ended conception of not just international accountability but legal accountability rests upon certain assumptions about international law. The central assumption is that law emerges from the interaction of the participants in the legal system and an increasingly fixed pattern of expectations about appropriate behaviour. ${ }^{12}$ In the international legal order, norms may settle into custom or may be enshrined through treaties. However, that which gives norms a

12. See J. Brunnée and S.J. Toope, 'International Law and Constructivism: Elements of an Interactional Theory of International Law’, 39 Columbia JTL (2000) p. 19. 
distinctly legal quality is not solely their formal validity. Rather, what distinguishes legal norms from broader social norms is certain internal characteristics of law, notably that rules must be compatible one with another, that they must ask reasonable things, that they are transparent and relatively predictable, and that known rules actually guide official discretion. ${ }^{13}$ In today's evolving international legal order it is all the more important that attention is paid to these traits, for they infuse legal norms with a particular legitimacy and enhance their ability to shape arguments, to persuade and to promote adherence. ${ }^{14}$ These traits, rather than formal legal status alone, are central to international law's ability to force justification, assessment or judgment, and thus to facilitate international legal accountability. They also anchor a concept of accountability that is both wider and more demanding than a purely formal account.

\section{INTERNATIONAL LEGAL ACCOUNTABILITY THROUGH STATE RESPONSIBILITY}

The law of state responsibility provides for a form of international legal accountability that is limited in several important respects: it is triggered only by breaches of positive international law; it applies only to breaches of international law by or attributable to a state and operates only when responsibility can be invoked by other states; it circumscribes the legal consequences of and remedies for a breach; and it limits the countermeasures that are available to states to induce compliance. The first of these issue clusters brings into play the primary rules of international law and explains why they have important implications for the extent to which the state responsibility regime can facilitate accountability. The latter three clusters of limitations flow exclusively from the secondary rules that make up the law of state responsibility proper. The following discussion considers primary and secondary rules in turn.

\section{$2.1 \quad$ Primary rules}

The fact that it is triggered only by the breach of a primary rule of positive international law limits the ability of the law of state responsibility to promote accountability before the secondary rules that it provides ever come into play. A few examples

13. See L.L. Fuller, The Morality of Law, rev. edn. (New Haven, Yale University Press 1969) pp. $39,46-91$.

14. J. Brunnée and S.J. Toope, 'Persuasion and Enforcement: Explaining Compliance with International Law', XIII Finnish YIL (2002) p. 273. 
may suffice to illuminate the spectrum of constraints that may arise already at the level of primary rules.

First, the majority of primary rules of general international law remain focused on states' rights and obligations. There is a growing range of rights and obligations of non-state actors under international law. Yet, as section 2.2 of this article illustrates, the secondary rules of the law of state responsibility limit the extent to which the state responsibility regime could channel accountability in this context. In particular, a state can invoke the responsibility of another only when its own legal interests are affected. In turn, whether that is the case depends in part upon the primary rule that has been breached. For example, where a state violates the human rights of its own citizens, and absent a treaty regime that would entitle all states parties to uphold the rights that it enshrines, third states could do so only when the violation infringed a norm that has erga omnes effect.

Thus, second, since the obiter dictum of the International Court of Justice (ICJ) in the 1970 Barcelona Traction case it is has come to be accepted that there exist 'obligations of a State towards the international community as a whole'. These obligations, 'by their very nature ... are the concern of all States' and 'all States can be held to have a legal interest in their protection'. ${ }^{15}$ In identifying certain norms as being owed erga omnes, international law has begun to transcend the classical bilateral conception of inter-state rights and obligations and has begun to articulate collective concerns. ${ }^{16}$ However, aside from certain core norms, such as the prohibition of genocide, the "principles and rules concerning the basic rights of the human person' ${ }^{17}$ and the right of peoples to self-determination, ${ }^{18}$ it remains difficult to identify erga omnes norms with certainty. ${ }^{19}$ Of course, the idea of collective interests finds expression also in areas of international law other than human rights. For example, international environmental law has seen the emergence of concepts such 'common areas', 'common heritage', and 'common concern' to deal with the fact that many environmental problems cannot be neatly tied to individual states' interests. ${ }^{20}$ And yet, debate continues on whether these concepts depend on treaty-

15. Barcelona Traction, Light and Power Company, Ltd. (Belgium v. Spain), ICJ Rep. (1970) p. 3 at p. 32 , para. 33 .

16. See generally B. Simma, From Bilateralism to Community Interest in International Law, RDC 250 (1994 VI).

17. Barcelona Traction case, supra n. 15, at p. 32, para. 34.

18. East Timor (Portugal v. Australia), ICJ Rep. (1995) p. 90 at p. 102, para. 29; Legal Consequences of the Construction of a Wall in the Occupied Palestinian Territory, Advisory Opinion, ICJ Rep. (2004) p. 131, paras. 88, 155 (concluding also that 'certain of its obligations under international humanitarian law' have erga omnes effect) [hereinafter Wall case].

19. For a detailed analysis, see M. Ragazzi, The Concept of International Obligations Erga Omnes (Oxford, Oxford University Press 1997). See also C. Tams, Enforcing Obligations Erga Omnes in International Law (Cambridge, Cambridge University Press 2005) Ch.4.

20. See J. Brunnée, 'Common Areas, Common Heritage and Common Concern', forthcoming in D. Bodansky, J. Brunnée and E. Hey, eds., Oxford Handbook of International Environmental Law (Oxford, Oxford University Press 2007) Ch. 24. 
regimes to unfold legal effects, or whether they exist at customary law and are endowed with erga omnes effect. The ICJ at least has so far not explicitly identified environmental obligations as having erga omnes quality. ${ }^{21}$

Third, the primary rules of general international law are often too open-textured to lend themselves easily to determinations of wrongfulness. For example, important aspects even of central international environmental norms remain opaque. The legal status and content of several key norms, such as the precautionary principle, sustainable development, or common but differentiated responsibilities, remain contested. While this fact does not impede these norms' ability to influence international environmental policy and shape environmental agreements, it does impact on their usefulness in a litigation context. ${ }^{22}$ Yet, even when the legal status of a norm is uncontested, as with the prohibition on serious transboundary harm, ${ }^{23}$ difficult questions remain to be answered before the responsibility of a state for a wrongful act can be invoked. When is transboundary harm sufficiently serious to violate the no harm rule? What types of harm are actionable; in particular, to what extent is purely ecological harm covered by the rule ${ }^{24}$ Once these questions are answered, certain types of harm may simply fall outside the scope of the primary rule. In the case of the no harm rule, states' rights to use their territories and resources find their limits when serious transboundary harm is inflicted, and other states must tolerate harm that remains below that threshold.

Finally, the primary rules of international law, rather than the rules governing responsibility, determine the standard of conduct that a state must transgress to commit a wrongful act. To continue with examples from international environmental law, fault liability, expressed through the requirement of due diligence, is the background rule under customary law. ${ }^{25}$ Thus, the no harm rule requires only that reasonable efforts are made to prevent harm. In the absence of agreed international

21. In Legality of the Threat or Use of Nuclear Weapons, Advisory Opinion, ICJ Rep. (1996) p. 226, para. 29, the Court observes: 'The existence of the general obligation of States to ensure that activities within their jurisdiction and control respect the environment of other States or of areas beyond national control is now part of the corpus of international law relating to the environment' [emphasis added]. While the passage confirms that states are obliged to respect environmental commons, it is left open whether other states would have standing to enforce compliance with that obligation.

22. See D. Bodansky, 'Customary (and not so Customary) International Environmental Law', 3 Indiana Journal of Global Legal Studies (1995) p. 105.

23. See Trail Smelter Arbitration, United Nations Reports of International Arbitral Awards 3 (1947) p. 1905. And see Nuclear Weapons case, supra n. 21.

24. See A. Boyle, 'Reparation for Environmental Damage in International Law: Some Preliminary Problems', in M. Bowman and A. Boyle, eds., Environmental Damage in International and Comparative Law (Oxford, Oxford University Press 2002) p. 17.

25. See T. Scovazzi, 'State Responsibility for Environmental Harm', 12 YIEL (2001) p. 43 at p. 55. See also, in the human rights context, D.-M. Chirwa, 'The Doctrine of State Responsibility as a Potential Means of Holding Private Actors Accountable for Human Rights', 5 Melbourne JIL (2004) p. 1 at pp. 11-18. 
standards, the difficulties that a claimant would face in establishing a lack of diligence on the part of another state exacerbate other evidentiary challenges, such as those related to causation. ${ }^{26}$ Only in relation to specific high-risk activities might there be a strict liability standard. ${ }^{27}$ However, it is debatable whether that is true as a matter of customary law, or only pursuant to specific treaty regimes. The upshot is that a considerable range of transboundary harm - that which is unforeseeable or unavoidable by reasonable efforts - falls beyond the scope of the primary rule, and thus beyond the reach of the state responsibility regime. ${ }^{28}$ This situation is compounded by the fact that most of the activities that give rise to transboundary environmental impacts are not state but private activities. These private actors are not subject to the relevant primary rules of international environmental law, ${ }^{29}$ so that a potentially significant accountability gap results when states are held only to a due diligence standard. ${ }^{30}$ A different situation may arise under environmental agreements in which states commit themselves to particular results, such as emission reductions or phase-outs of hazardous substances and processes. ${ }^{31}$ However, states have not relied upon the state responsibility regime to address violations of such treaty commitments. Rather they have opted for treaty-based non-compliance procedures, which are discussed in section 3.2.3 of this article.

\section{$2.2 \quad$ Secondary rules}

The rules of the law of state responsibility itself further define the degree to which the regime can serve as an accountability mechanism. Three issue clusters are considered here. First, as the very label 'state responsibility' suggests, not all breaches of international law are captured by the responsibility regime outlined in the ILC Draft Articles. Second, the rules on the legal consequences of an internationally wrongful act and the range of available remedies imply a conception of accountability that is strongly focused upon restoring the rights of injured states. Third, the rules on countermeasures reinforce this primary concern with accountability vis-àvis injured states.

26. See P. Birnie and A. Boyle, International Law and the Environment, 2nd edn. (Oxford, Oxford University Press 2002) at p. 189.

27. See A.E. Boyle, 'Globalising Environmental Liability: The Interplay of National and International Law', 17 Journal of Environmental Law (2005) p. 3 at p. 8.

28. See ibid., at pp. 6-7.

29. See e.g., C.M. Vasquez, 'Direct vs. Indirect Obligations of Corporations under International Law', 43 Columbia JTL (2005) p. 927.

30. Similar questions arise in other areas of international law, such as whether and when states can be accountable for human rights abuses by corporations and other private actors under their jurisdiction. See Chirwa, supra n. 25, at pp. 11-18.

31. See Bodansky and Crook, supra n. 6, at p. 783. 


\subsubsection{Breaches of international law - the reach of the state responsibility regime}

The first cluster raises two equally important sets of issues. On the one hand, not all breaches of international law will constitute 'wrongful acts' within the terms of the state responsibility regime. On the other hand, not in all cases of wrongful acts within the meaning of the regime will actors necessarily be able to invoke the responsibility of a state.

\subsubsection{Wrongful acts by, or attributable, to states - what are states accountable for?}

As noted above, in most situations there are no primary rules of international law that would impose obligations upon non-state actors. However, even where such obligations do exist, such as under international criminal law norms applicable to individuals or treaties and custom applicable to international organizations, breaches by these actors are not captured directly by the draft Articles' regime. While the regime does not preclude the responsibility of individuals under international law, ${ }^{32}$ it applies only to internationally wrongful acts by states, that is to acts or omissions that constitute a breach of a state's international obligations. ${ }^{33}$

There will be no state responsibility for violations of international law by nonstate actors unless a state either had an obligation to prevent the conduct in question, or the conduct can be attributed to the state. ${ }^{34} \mathrm{~A}$ well-known example of the former situation arose in the Tehran Hostages case, in which the International Court of Justice (ICJ) determined that Iran had a duty to protect the US embassy in Tehran and its diplomatic personnel from being overrun by demonstrators. ${ }^{35}$ However, as illustrated by the earlier examples drawn from international environmental law, states' obligations will frequently hinge upon a due diligence standard so that it will be difficult to hold states accountable for private conduct. If a state cannot be held responsible for a separate breach of one of its obligations, the question becomes whether or not the violations of a non-state actor can be imputed to the state.

32. See ILC Draft Articles, supra n. 11, Art. 58. Indeed, in certain circumstances, both a nonstate actor and a state may be responsible under international law. For example, an individual may be responsible for acts such as crimes against humanity or torture under international criminal law, while a state may be responsible for these acts to the extent that they are attributable to it under the rules of state responsibility. See A. Nollkaemper, 'Concurrence between Individual Responsibility and State Responsibility in International Law', 52 ICLQ (2003) p. 615. And see infra section 3.1.1 (at n. 118).

33. ILC Draft Articles, ibid., Arts. 1 and 2.

34. See generally, Chirwa, supra n. 25.

35. US Diplomatic and Consular Staff in Tehran (US v. Iran), ICJ Rep (1980) p. 3 at pp. 3032. 
The draft Articles outline a range of situations in which non-state actor conduct can be attributed to a state such as to make them acts of the state. Since states always act through persons who exercise their powers and authority, the practically most important of these situations are those involving actions that amount to official conduct. ${ }^{36}$ In addition, responsibility may arise for conduct that was directed or controlled by a state, ${ }^{37}$ the conduct of insurrectional movements, ${ }^{38}$ or conduct that a state adopted as its own. ${ }^{39}$ Again, however, many difficult accountability questions remain unanswered, such as those raised in current debates on the circumstances under which states can be held legally responsible for terrorist activities. $^{40}$

\subsubsection{Invocation of responsibility - to whom are states accountable?}

Turning to questions of who can invoke the responsibility of a state in what circumstances, further limitations arise with respect to non-state actors. Aside from the fact that non-state actors cannot invoke the responsibility of states under the ILC regime, even states may not be able to invoke all breaches affecting non-state actors. ${ }^{41}$ Put differently, even where primary rules exist that protect non-state actors, such as human rights norms, the ILC regime provides accountability only to the extent that states are entitled to invoke them. That entitlement lies primarily with states that were 'injured' by the breach (Art. 42), although the ILC articles do outline circumstances in which other states can invoke responsibility for a breach (Art. 48). Of course, the articles' approach to the invocation of responsibility raises questions not only regarding the extent to which accountability for violations of non-state actors' rights can be channeled. Similar questions arise generally with

36. ILC Draft Articles, supra n. 11, Arts. 4-6. See also Art. 9.

37. Ibid., Art. 8.

38. Ibid., Art. 10

39. Ibid., Art. 11. This type of situation also arose in the Tehran Hostages case, where the initial invasion of the US embassy by demonstrators was not attributable to Iran, but where the subsequent occupation of the embassy became attributable when the Iranian government began to support it. See US Diplomatic and Consular Staff in Tehran case, supra n. 35, at pp. 34-35.

40. See e.g., D. Jinks, 'State Responsibility for the Acts of Private Armed Groups', 4 Chicago JIL (2003) p. 83; A. Nollkaemper, 'Attribution of Forcible Acts to States: Connections Between the Law on the Use of Force and the Law of State Responsibility', in N. Blokker and N. Schrijver, eds., The Security Council and the Use of Force: Theory and Reality - A Need for Change? (Leiden, Martinus Nijhoff Publishers 2005) p. 133.

41. For the purposes of the Draft Articles, the invocation of responsibility involves 'measures of a relatively formal character, for example, ... a claim against another State or the commencement of proceedings before an international court or tribunal. A State does not invoke the responsibility of another State merely because it criticizes that State for a breach and calls for the observance of the obligation, or even reserves its rights or protests.' See International Law Commission, Report on the Work of Its Fifty-Third Session (23 April-1 June and 2 July-10 Augusts 2001) UN Doc. A/56/10, Commentary to Art. 42, p. 294, para. 2 [hereinafter ILC Commentary]. 
respect to norms that protect legal interests other than those of individual states.

A state can invoke another's responsibility as an 'injured state' for the breach of an obligation that was owed to it individually. ${ }^{42}$ A state can also be injured by the breach of an obligation owed to a group of states of which it is part (obligations erga omnes partes), or owed to the international community (obligations erga omnes), so long as it is specially affected by the breach or the breach radically changes the position of the states to which the obligation is owed.$^{43}$ In other words, the violation of a state's legal interest in the upholding of collective or community obligations alone is not treated in the draft Articles as 'injury'. Rather, in such cases a state can invoke another's responsibility only as a non-injured state, with attendant limitations upon what it can claim from the responsible state and what measures it can take to ensure compliance. ${ }^{44}$ The ILC settled upon this narrow conception of injury and the distinction between injured and non-injured states for the purposes of invocation of responsibility only after protracted deliberations and consideration of a range of alternative options. ${ }^{45}$ Articles 42 and 48 are at the core of the ILC's effort to strike a series of delicate, interrelated compromises: between the traditional bilateralism of the law of state responsibility and the rise of collective legal interests; ${ }^{46}$ between the need to anchor the draft Articles in the established, bilateralist state practice and the need to allow for a maturing of international law's communitarian traits ${ }^{47}$ and between concerns that a wider conception of injury might expose states to excessive claims for violations of collective interests and concerns that violations of norms that protect important collective or community interests be accorded appropriate significance in the responsibility regime. ${ }^{48}$

The balance struck in the draft Articles limits the circumstances and manner in which states can hold one another accountable for infringements of collective legal interests. These limitations can be illustrated in the above-mentioned context of violations of rights of non-state actors, such as human rights. While human rights obligations are owed to individuals, individuals have relatively limited options for the vindication of these rights at the international level, ${ }^{49}$ options that do not include direct recourse to the state responsibility regime as set out in the draft Ar-

42. ILC Draft Articles, supra n. 11, Art. 42(a).

43. Ibid., Art. 42(b).

44. ILC Draft Articles, supra n. 11, Arts. 48, 54. See also infra sections 2.2.2 and 2.2.3.

45. For a detailed analysis, see P.-M. Dupuy, 'A General Stocktaking of the Connections between the Multilateral Dimension of Obligations and Codification of the Law of Responsibility', 13 EJIL (2002) p. 1053.

46. See I. Scobbie, 'The Invocation of Responsibility for the Breach of 'Obligations under Peremptory Norms of General International Law', 13 EJIL (2002) p. 1202 at p. 1204.

47. Ibid., at p. 1218 .

48. See M. Koskenniemi, 'Solidarity Measures: State Responsibility as a New International Legal Order', 72 BYIL (2001) p. 337 at pp. 348-349.

49. See generally M. Kaplan, 'Using Collective Interests to Ensure Human Rights: An Analysis the Articles on State Responsibility', 79 NY Univ. LR (2004) p. 1902. 
ticles. The ability of other states to hold a state that perpetrates human rights violations legally accountable thus assumes particular importance. Essentially, under the draft Articles, states could invoke responsibility for breaches of human rights obligations when their nationals are affected, when human rights obligations are also owed to them as a party under a treaty, or when the relevant obligations are owed to the international community as a whole. Which type of obligation is at issue is determined by the primary rules of international law, rather than the rules that govern state responsibility. However, as noted in section 2.1 above, the latter rules determine the circumstances in which a state will be deemed to have suffered injury, and the extent to which it can invoke violations of collective norms when it is not specially affected by them.

By including collective or community interest norms in the Draft Articles, the ILC did reflect the gradual development away from bilateralism in the primary norms of international law. By providing that even states that are not specially affected by a violation have a legal interest in the upholding of community norms and are entitled to invoke responsibility for violations, the Draft Articles follow the course charted by the ICJ in the above-quoted passage of the Barcelona Traction case.$^{50}$ For many commentators, the right of each state to invoke responsibility for violations is inherent in the very concept of obligations erga omnes..$^{51}$ However, the ICJ has not pronounced itself specifically on this point, ${ }^{52}$ nor is there clear state practice. ${ }^{53}$ The ILC, therefore, treads cautiously on the questions whether and to what extent all states have standing to hold violators to account for violations of erga omnes norms. ${ }^{54}$ The Draft Articles chose a compromise course that endorses the idea of public interest standing but also narrows the range of available remedies and countermeasures.

50. See supra n. 15 and accompanying text.

51. See Simma, supra n. 16 , at p. 296.

52. In the Barcelona Traction case, supra n.15, the Court found all states to have a legal interest in the upholding of community norms. Yet, at para. 91, the Court seemed to require a concrete treaty mechanism to provide standing, thus hinting at a distinction between the two issues. In the East Timor case, supra n. 18, the Court merely commented on the erga omnes status of the right to self-determination, not on its implications for the standing of third states. In South West Africa, Second Phase, ICJ Rep. (1966) p. 6 at p. 47, para. 88, the ICJ had rejected the existence of an actio popularis in international law. However, that ruling has been subject to much criticism and, in Art. 48 of the Draft Articles, the ILC opted for a deliberate departure from it. See ILC Commentary, supra n. 41, at p. 321 (fn. 766).

53. See Ragazzi, supra n. 19, at pp. 212-214. But see also Tams, supra n. 19, at pp. 196-197. Of course, some treaties specifically allow states to bring complaints in the absence direct injury. For examples, see E. Brown Weiss, 'Invoking State Responsibility in the Twenty-First Century', 96 AJIL (2002) p. 798 at pp. 805-806.

54. Arguably, this caution is warranted in view of the fact that the concepts of obligations erga omnes and standing, while related, are legally distinct. On the distinction, see Ragazzi, supra n. 19, at p. 212; Tams, supra n. 19, at pp. 139-151. 


\subsubsection{Legal consequences of internationally wrongful acts and available remedies}

The legal consequences that a breach triggers for the responsible state are the same whether the relevant obligation was owed to an individual state, to several states, or to the international community as a whole. ${ }^{55}$ In all cases, the responsible state must cease the violation, ${ }^{56}$ must offer necessary assurances of non-repetition, ${ }^{57}$ and must make full reparation for the injury caused. ${ }^{58}$ These secondary obligations arise directly from the breach by a state of its primary legal obligations, and thus regardless of whether or not that state's responsibility is invoked by another. This point is important in view of the fact that the Draft Articles' distinction between injured and non-injured states serves to limit not only the ability of states to invoke others' responsibility but also the remedies that they could seek.

Only injured states can claim the full spectrum of remedies from the responsible state, including reparation for the injury suffered. Non-injured states may only claim cessation and assurances of non-repetition. ${ }^{59}$ Since the Draft Articles do not treat the mere violation of states' legal interest as 'injury', such states are not entitled to reparation. However, they may claim reparation 'in the interest of the injured state or of the beneficiaries of the obligation breached'. ${ }^{60}$ The latter option is remarkable insofar as it is intended to "provide a means of protecting the community or collective interest at stake' ${ }^{61}$ The separate reference to 'beneficiaries of the obligation' suggests the possibility of claims for reparation on behalf of non-nationals, for example for violations of their human rights. The ILC acknowledges that this collective or community interest remedy, with respect to both claims on behalf of injured states and claims on behalf of non-state actors, 'involves a measure of progressive development' ${ }^{62}$ In any case, even if the idea as such were to be embraced by international practice, its potential will be reigned in by the nationality of claims rule, which the Draft Articles specifically declare to be applicable to claims by both injured and non-injured states. ${ }^{63}$ While this rule may not bar a state from invoking the responsibility of another for the violation of collective or com-

55. ILC Draft Articles, supra n. 11, Art. 33(1).

56. Ibid., Art. 30(a).

57. Ibid., Art. 30(b).

58. Ibid., Art. 31. Reparation encompasses restitution (the re-establishment of the situation that existed prior to the act), compensation for damage, and satisfaction. See ibid., Arts. 34-37.

59. Ibid., Art. 48(2)(a).

60. Ibid., Art. 48(2)(b).

61. ILC Commentary, supra n. 41, at p. 323.

62. Ibid.

63. ILC Draft Articles, supra n. 11, Arts. 44(a) and 48(3). 
munity obligations, it arguably does preclude claims for reparation on behalf of victims of human rights violations. ${ }^{64}$

The uncertainty regarding such claims underscores the importance of the fact that the responsible state is nonetheless under a duty to cease the violation and to make reparation for damage, including damage suffered by non-state actors whose rights were violated. For example, in its Advisory Opinion on The Legal Consequences of the Construction of a Wall in the Occupied Palestinian Territory, the ICJ concluded that Israel had violated the right of the Palestinian people to selfdetermination. ${ }^{65}$ It held that Israel not only had an obligation to end the violation but also to make reparation for the damage caused ${ }^{66}$ either by 'returning the land, orchards, olive groves and other immovable property seized from any natural or legal person for purposes of construction of the wall in the Occupied Palestinian Territory', or by compensating 'all natural or legal persons having suffered any form of material damage as a result of the wall's construction'. ${ }^{67}$

The ILC's efforts to strengthen the communitarian threads in the otherwise bilateralist fabric of the law of state responsibility are also evident in the Draft Articles' treatment of 'serious breaches' of peremptory norms of international law. ${ }^{68}$ The existence of a category of peremptory norms appears to be accepted. ${ }^{69}$ Which norms are encompassed in that category, however, remains difficult to say. ${ }^{70}$ The categories of peremptory norms, or jus cogens, and of erga omnes norms overlap to a significant extent. ${ }^{71}$ Yet, the two categories are conceptually distinct. As the ILC Commentary to the Draft Articles observes, while the former category focuses 'on the scope and priority to be given to a certain number of fundamental obligations', the latter's focus 'is essentially on the legal interest of all states in compliance'. ${ }^{72}$ The Draft Articles reflect this conceptual distinction by treating the two categories separately, in Part Two on the legal consequences of wrongful acts and Part Three on the invocation of responsibility, respectively. Indeed, the separation of the questions raised by the peremptory and erga omnes qualities of norms played a significant role in enabling the ILC to advance the state responsibility project to

64. For a helpful discussion, see Scobbie, supra n. 46, at pp. 1213-1219.

65. Wall case, supra n. 18, para. 122.

66. Ibid., paras. 150-152.

67. Ibid., para. 153 .

68. ILC Draft Articles, supra n. 11, Arts. 40 and 41. A 'serious violation "involves a gross or systematic" breach'. See ibid., Art. 40(2).

69. See Arts. 53 and 64 of the Vienna Convention on the Law of Treaties, UNTS 1155 (1969) p. 331 (stipulating that treaties that purport to derogate from a peremptory norm are invalid).

70. See e.g., M. Shaw, International Law, 5th edn. (Cambridge, Cambridge University Press $2003)$ at p. 118.

71. ILC Commentary, supra n. 41, p. 281.

72. Ibid. But see Dupuy, supra n. 45, at p. 1074 (arguing that the ILC did not go far enough in drawing out the distinction between jus cogens and obligations erga omnes). 
completion. Previous approaches to the thorny issues raised by norms of essential interest to the international community, such as reliance on the concept of international crimes of states, had stymied the ILC project. $^{73}$

Absent state practice on punitive or otherwise elevated legal consequences of a jus cogens violation for the responsible state, the Draft Articles confine themselves to declaring the ordinary consequences of a breach of international law to be applicable. ${ }^{74}$ However, the Draft Articles do envisage special consequences for other states in the face of such violations. Third states are under an obligation to cooperate to end a serious breach through lawful means, ${ }^{75}$ and they may not recognize a situation created by a serious breach or assist in maintaining that situation. ${ }^{76}$

For the time being, it is difficult to identify state practice that explicitly relies upon the peremptory character of legal norms and the ICJ, while it has invoked the erga omnes effect of certain norms, has avoided pronouncing itself on their peremptory nature. ${ }^{77}$ Interestingly, in its Advisory Opinion in the Wall case, the Court concluded that 'all States are under an obligation not to recognize the illegal situation', 'not to render aid or assistance in maintaining the situation created' by the construction of the wall, and 'to see to it that any impediment, resulting from the construction of the wall, to the exercise by the Palestinian people of its right to selfdetermination is brought to an end'. ${ }^{78}$ These third state obligations bear striking resemblance to the legal consequences that the Draft Articles attach to breaches of peremptory norms. However, the ICJ instead anchored these consequences in the erga omnes nature of the right to self-determination, ${ }^{79}$ an approach for which it was sharply criticized by some of its members. ${ }^{80}$

73. See Crawford, supra n. 7, at pp. 16-20, 35-38.

74. ILC Draft Articles, supra n. 11, Art. 41(3).

75. Arguably, this obligation is intended to apply also to the responsible state. See ILC Draft Articles, ibid., Art. 41(1), which stipulates simply that 'States shall cooperate to bring to an end ... any serious breach'.

76. Ibid., Art. 41(1)-(2).

77. Its reluctance to do so may account for its reliance on the erga omnes concept, rather than the concept of jus cogens, to explain the legal consequences of Israel's violation of the Palestinian right to self-determination for third states in the Wall case, supra n. 18, paras. 154-160. Note that Judge Kooijmans, in his Separate Opinion, supra n. 18, para. 40, tied his analysis to the legal consequences of breaches of peremptory norms as outlined in Arts. 40 and 41 of the Draft Articles on State Responsibility.

78. Wall case, supra n. 18, para. 159.

79. Ibid., paras. 154-160.

80. See Separate Opinion of Judge Higgins, Wall case, supra n. 18, para. 37 (noting that she did not 'think that the specified consequence [sic] of the identified violations of international law have anything to do with the concept of erga omnes'); Separate Opinion of Judge Kooijmans, Wall case, supra n. 18, para. 40 (admitting 'considerable difficulty in understanding why a violation of an obligation erga omnes by one State should necessarily lead to an obligation for third States'). 
The ILC acknowledged that the Draft Articles' stipulation of a duty to cooperate to counteract serious violations of peremptory norms may reach beyond what 'general international law at present prescribes' ${ }^{81}$ The goal of this element of progressive development was 'to strengthen existing mechanisms of cooperation, on the basis that all States are called upon to make an appropriate response to' serious breaches of peremptory norms. ${ }^{82}$ So far, the responses from government and scholarly circles have been reserved at best. ${ }^{83}$

In sum, when it comes to the legal consequences of a breach of international law and available remedies, the Draft Articles offer a careful blend. In keeping with the classical bilateral paradigm, the focus is predominantly upon the rights of injured states. With respect to consequences of or remedies for collective or community interests, the Draft had to venture into the realm of progressive development of international law. However, regardless of individual, collective or community nature of the rights at issue, and whether or not its responsibility is invoked, the responsible state is under an independent obligation to return to compliance and to repair the injury it caused. Overall, then, while the range of available remedies remains uncertain, legal consequences are envisaged for all violations of international law that otherwise fall within the parameters of the Draft Articles. ${ }^{84}$

\subsubsection{Countermeasures}

Like the Draft Articles' approach to remedies, its approach to countermeasures is tethered to the distinction between injured and other states. Only an injured state may take 'countermeasures'. ${ }^{85}$ In the scheme set out by the Draft Articles, these are measures that violate the obligations owed by the injured state to the responsible state; their wrongfulness is precluded only by the fact that they respond to a prior violation by the responsible state. ${ }^{86}$ Of course, countermeasures may not involve the violation of the prohibition on the threat or use of force, fundamental human rights obligations, or other obligations of peremptory character. ${ }^{87}$

Notwithstanding the fact that countermeasures are responses to prior violations of international law, their purpose as captured in the Draft Articles is not puni-

81. ILC Commentary, supra n. 41, at p. 287.

82. Ibid

83. See D. Shelton, 'Righting Wrongs: Reparations in the Articles on State Responsibility', 96 AJIL (2002) p. 833 at p. 842.

84. See ibid., passim (emphasizing throughout the importance of the distinction between the secondary obligations of the responsible state and remedies).

85. ILC Draft Articles, supra n. 11, Art. 49.

86. Ibid., Art. 22. And see ILC Commentary, supra n. 41, at p. 324.

87. ILC Draft Articles, supra n. 11, Art. 50(1). Nor is a state taking countermeasures relieved from obligations under an applicable dispute settlement procedure or obligations regarding diplomatic or consular privileges. See also Art. 50(2). 
tive ${ }^{88}$ Rather, their role is to induce the responsible state to comply with the obligations that flow from its internationally wrongful act. ${ }^{89}$ In other words, strictly speaking, countermeasures do not focus upon the initial violation of a primary rule of international law, but the violation of the resultant secondary obligations - cessation, non-repetition, and reparation. Where the responsible state fails to comply with these secondary obligations, countermeasures bring an element of enforcement into the state responsibility regime.

The role of countermeasures must therefore be appreciated in light of the background assumption of a largely decentralized legal system, where self-help may be the only available means of enforcement. ${ }^{90}$ That said, their objective - to induce compliance with a responsible state's secondary obligations - also imports various limitations on the self-help options available to an injured state. Most notably, once the responsible state has complied with its obligations, countermeasures must be terminated. ${ }^{91}$ Thus, countermeasures must by definition be temporary and reversible. ${ }^{92}$ One might have expected that countermeasures also should be proportional to what is required to actually induce the compliance of the responsible state. ${ }^{93}$ However, the ILC appears to have seen that idea as inherent in the prescription that countermeasures may only be taken in order to induce compliance. ${ }^{94}$ Therefore, while the Draft Articles do stipulate a proportionality requirement, it is intended to further limit the scope of otherwise permissible response action. ${ }^{95}$ Countermeasures must be 'commensurate with the injury suffered, taking into account the gravity of the internationally wrongful act and the rights in question' ${ }^{96}$

All of these features of the countermeasures regime - the role of countermeasures as measures to induce compliance, the attendant notion that countermeasures be temporary and reversible, and the proportionality requirements - are elements of the Draft Articles' wider effort to balance the need for self-help against the risk of abuse and escalation of countermeasures. ${ }^{97}$ Arguably, this preoccupation also animates the requirement that any resort to countermeasures be preceded not only by a prior appeal to the responsible state for compliance, but also its prior notifica-

88. See Bederman, supra n. 9, at p. 822 (suggesting that this focus may not fully comport with earlier international law sources).

89. ILC Draft Articles, supra n. 11, Art. 49(1).

90. ILC Commentary, supra n. 41, at p. 324.

91. ILC Draft Articles, supra n. 11, Art. 53.

92. Ibid., Arts. 49 (2)-(3 and 53.

93. See Bederman, supra n. 9, at p. 822 .

94. The ILC acknowledges that '[i]n some respects proportionality is linked to the requirement of purpose specified in article 49', but adds that proportionality is a 'limitation even on measures which may be justified under article 49'. See ILC Commentary, supra n. 41, at p. 344.

95. See ibid.

96. ILC Draft Articles, supra n. 11, Art. 51.

97. See generally ILC Commentary, supra n. 41, at pp. 324-328. 
tion of pending countermeasures and an offer to negotiate. ${ }^{98}$ Perhaps most importantly, however, concerns about abuse help explain the Draft Articles' very cautious approach to self-help in the face of violations of collective or community obligations.

Just as the remedies that a non-injured state may seek for violations of collective or community obligations are significantly more confined than those available to an injured state, so are the response actions. In essence, the Draft Articles provide a savings clause rather than a rule that would govern response action by noninjured states. Article 54 merely stipulates that the Draft Articles provisions on countermeasures do 'not prejudice the right of any State, entitled under Article 48, paragraph 1, to invoke the responsibility of another State' and 'to take lawful measures against that State to ensure cessation of the breach and reparation in the interest of the injured State or of the beneficiaries of the obligation breached'. ${ }^{99}$

Article 54 builds on the tentative attempt in Article 48 to provide a remedy for violations of collective or community obligations. But just as the existence at international law of a non-injured state's right to seek a remedy on behalf of another state or the beneficiaries of the obligation is uncertain, so is the existence of a right of non-injured states to take countermeasures. ${ }^{100}$ The opinions of states and academic observers alike remain divided. For some the very importance of the collective or community interests at issue demands that states be able to induce compliance through countermeasures. ${ }^{101}$ For others, the fact that it is individual states that would decide whether or not to take countermeasures, combined with the inequalities among states, raise the spectre of abuse and even 'vigilantism' by powerful states. ${ }^{102}$ Indeed, much of the existing practice of countermeasures taken in the collective interest is that of powerful western states, ${ }^{103}$ a pattern that led many other states to argue that this practice had to be discounted in assessing the state of international law. ${ }^{104}$ This assessment was ultimately shared by the ILC, which concluded that 'practice is sparse and involves a limited number of states'. ${ }^{105}$ As a result, the ILC considered that it was premature to permit non-injured states to take

98. ILC Draft Articles, supra n. 11, Art. 52(1).

99. Ibid., Art. 54.

100. See ILC Commentary, supra n. 41, at p. 355 (observing that 'there appears to be no clearly recognized entitlement of States referred to in article 48 to take countermeasures in the collective interest').

101. See Kaplan, supra n. 49, at p. 1913.

102. See e.g., Koskenniemi, supra n. 48, at p. 348; Brown Weiss, supra n. 53, at p. 805.

103. See ILC Commentary, supra n. 41, at pp. 351-353. Note also that some of the relevant practice was justified on other legal grounds. See id., at p. 354. But see Tams, supra n. 19, at pp. 235-236 (emphasizing the diversity of Western states that have taken collective interest countermeasures, and pointing to some practice by non-Western states).

104. See Kaplan, supra n. 49, at pp. 1919-1920.

105. See ILC Commentary, supra n. 41, at p. 355. 
countermeasures in response to violations of collective interests and opted for a provision that 'reserves the position and leaves the resolution of the matter to the further development of international law'. ${ }^{106}$ Whether or not this goal is in effect accomplished by the savings clause is a matter of debate. Some observers worry that the provision's reference to 'lawful measures' precludes future recourse to countermeasures, given that the latter are 'by definition intrinsically wrongful'. ${ }^{107}$ Others appear to expect the opposite outcome, arguing that 'a savings clause that notionally makes no law is actually intended to induce significant state practice' toward the progressive development of international law. ${ }^{108}$

\section{ALTERNATIVE MODES OF INTERNATIONAL LEGAL ACCOUNTABILITY}

When international law is examined through the law of state responsibility, it becomes evident that the accountability limitations that are rooted in the normative structure of international law are mirrored or even amplified by procedural limitations. The law of state responsibility is anchored in a formal, inter-state, understanding of international law and international legal process. Not only is the invocation of responsibility premised upon the claim of a violation of a formal legal rule; invocation itself involves 'measures of a relatively formal character'. These measures might include 'a claim against another state or the commencement of proceedings before an international court or tribunal'. However, a 'State does not invoke the responsibility of another State merely because it criticizes that State for a breach and calls for the observance of the obligation, or even reserves its rights or protests'. ${ }^{109}$ The essential problem is that, even when their individual or collective legal interests are at issue, states only rarely take the steps required to formally invoke the law of state responsibility.

It is all the more important, then, that the frameworks for international legal accountability have grown considerably beyond the state responsibility paradigm. International law has developed at the level of primary norms as well as secondary norms, and through both 'hard' and 'soft' legal norms and processes. An illustrative selection of these developments is canvassed in this third part of the article, again beginning with primary rules and then turning to secondary rules and accountability processes.

106. Ibid

107. See D. Alland, 'Countermeasures of General Interest', 13 EJIL (2002) p. 1220, at p. 1233.

108. See Bederman, supra n. 9, at p. 828 .

109. See ILC Commentary, supra n. 41. 


\subsection{Primary rules}

Seen through the lens of the law of state responsibility, the primary rules of international law appear to narrow the terrain of legal accountability. A further look quickly reveals, however, it is the lens rather than the terrain that is narrow. Norms have evolved that push beyond the traditional state-centric outlook of international law to obligate and entitle a range of other actors. There has also been a good deal of normative development that engages collective or community concerns. An increasingly dense normative fabric has been superimposed on the 'open texture' of many of the general rules of international law. Finally, the general standard of due diligence that underpins determinations of wrongfulness has been supplanted at least in some areas by strict or other alternative liability standards. ${ }^{110}$ Only relatively few of these developments expand the potential area of application of the law of state responsibility, in part because the relevant norms are concerned with the rights and obligations of actors other than states and in part because not all of these norms are 'hard' law. But that does not mean that the evolving primary rules do not facilitate accountability at all, or that the foundations for alternative processes of accountability cannot be built.

\subsubsection{Non-state actors}

International law is evolving to obligate and entitle a variety of non-state actors, including, in particular, international organizations, individuals and transnational corporations.

There is little doubt that, within their areas of activity, intergovernmental organizations can have customary or treaty-based international obligations. ${ }^{111}$ For example, the United Nations is arguably subject to human rights obligations that exist under general international law, including a duty to prevent genocide. ${ }^{112}$ Thus it is not so much the absence of primary rules that limits the accountability of international organizations, as the need for further development of the relevant secondary rules. The most important initiatives under way to address this gap, the efforts of the ILC to elaborate articles on the responsibility of international organizations and the work of the International Law Association (ILA) on accountability of inter-

110. The development of liability standards implicates both primary and secondary rules. Since it has relatively greater implication for the latter, it is discussed in section 3.2.1 below.

111. See Advisory Opinion on Interpretation of the Agreement of 25 March 1951 between the WHO and Egypt, ICJ Rep. (1980) p. 73, at p. 90.

112. See generally ILA, supra n. 2, p. 193. On the duty to prevent genocide, see G. Gaja, Third report on responsibility of international organizations, UN Doc. A/CN.4/553 (13 May 2005) p. 4 (para. 10). See also S.J. Toope, 'Does International Law Impose a Duty upon the United Nations to Prevent Genocide?', 46 McGill LJ (2000) p. 187. 
national organizations, ${ }^{113}$ are highlighted in section 3.2.2 below, and explored in detail in separate articles in this volume. Suffice it to note here that one of these initiatives, the ILA project, does extend into the realm of primary norms. The 'recommended rules and practices' sketched out by the ILA project include both legal obligations and soft standards of good governance. ${ }^{114}$

The most significant developments regarding international obligations of nonstate actors have occurred in the area of international criminal law. ${ }^{115}$ Indeed, there may be some irony in the fact that key elements of international legal personality of individuals first consolidated in this context, rather than in the area of human rights. ${ }^{116}$ While states have been reluctant to admit new actors into the circle of international right holders, there was readiness to see individuals rather than states held accountable for some of the most grievous violations of international law. ${ }^{117}$ The result has been a separate system of accountability, notwithstanding the possibility that states could also be held accountable under the law of state responsibility for international crimes that are attributable to them. ${ }^{118}$

When it comes to obligations of a very different, but increasingly important, type of non-state actor, the transnational corporation (hereinafter TNC), the reasons why the development of international norms has not translated into greater international legal accountability are slightly different. They flow from the fact that, unlike individuals or intergovernmental organizations, TNCs are not recognized as subjects of international law. ${ }^{119}$ As a result, there has so far been no development of positive international law towards a separate system of formal legal accountability. ${ }^{120}$ Instead, efforts to promote TNC accountability proceed through codes of conduct and other non-legally binding initiatives that seek to incorporate human rights, environmental or labour standards. ${ }^{121}$ While these strategies may

113. See ILC, Report of the International Law Commission on the Work of Its Fifty-seventh Session, UN GAOR, 60th Sess., Supp. No. 10, p. 73, UN Doc. A/60/10 (2005); ILA, supra n. 2.

114. See ILA, supra n. 2, p. 172, at pp. 187-188.

115. See e.g., M.C. Bassiouni, Introduction to International Criminal Law (Ardsley NY, Transnational Publishers 2003); P. Sands, ed., From Nuremberg to The Hague: The Future of International Criminal Justice (Cambridge, Cambridge University Press 2003).

116. See H. Kindred et al., eds., International Law Chiefly as Applied in Canada, 7th edn. (Toronto, Emond Montgomery 2006) at p. 70.

117. This point is not intended to take away from the observation of the Nuremberg War Crimes Tribunal that "crimes against international law are committed by men, not by abstract entities." See (1947), 1 Trial of the Major War Criminals, p. 171.

118. See Nollkaemper, supra n. 32.

119. See Shaw, supra n. 70, at p. 225. However, many observers would allow that TNCs enjoy at least 'elements of legal personality'. See e.g., Kindred, supra n. 116, at p. 68.

120. See Nollkaemper, supra n. 5, at p. 183.

121. See Vasquez, supra n. 29. And see D. Kinley and J. Tadaki, 'From Talk to Walk: The Emergence of Human Rights Responsibilities for Corporations under International Law', 44 Virginia JIL (2004) p. 931. 
eventually crystallize into norms of international law, they remain in the realm of 'soft law' for the time being. For example, the 2003 'Norms on the Responsibilities of Transnational Corporations and Other Business Entities with Regard to Human Rights' are phrased in terms of direct obligations by TNCs. ${ }^{122}$ At the moment, however, these norms neither reflect customary international law nor are they likely to be adopted in a form that would give them binding effect. ${ }^{123}$ International legal responsibility thus remains indirect, in the sense that TNC conduct must breach positive international law in a manner that is attributable to a state. ${ }^{124}$

Turning from obligations to the international rights of non-state actors, ${ }^{125}$ some brief points may suffice. First, it has been established since the ICJ's Advisory Opinion in the Reparations case that international organizations not only have such rights but also the capacity to raise claims for breaches. ${ }^{126}$ While an unlikely scenario, it is thus conceivable that an international organization could rely upon the law of state responsibility to hold a state accountable for a breach of its rights by that state, or attributable to that state. Second, as far as the legal position of individuals is concerned, the corpus of human rights law has of course seen steady development. However, at least from the vantage point of the state responsibility regime, that development as such does not necessarily enhance accountability options. Rather, the main impediments to this mode of accountability for human rights violations are the uncertainties as to which rights have peremptory character and erga omnes effect. As the discussion of the state responsibility regime has shown, absent primary norms that have these special characteristics, or treaty rules that create obligations erga omnes partes, the circumstances in which states can hold one another accountable for human rights violations are limited. It does not appear that international law is making huge strides in settling or expanding the range of general norms that have the requisite status. ${ }^{127}$ Third, with respect to TNCs, the situation remains opaque, as there continues to be resistance to the notion that

122. The 'Norms' were adopted by the UN Human Rights Commission's Sub-Commission on the Promotion and Protection of Human Rights, 55th Sess., 22d mtg., Agenda Item 4, UN Doc. E/ CN.4/Sub.2/2003/12/Rev. 2 (2003). The Sub-Commission had established a working group composed of five legal experts, led by Professor David Weissbrodt. See D. Weissbrodt and M. Kruger, 'Norms on the Responsibilities of Transnational Corporations and Other Business Entities with Regard to Human Rights', 97 AJIL (2003) p. 901 at p. 904.

123. For a detailed analysis see Vasquez, supra n. 29. But see also Nollkaemper, supra n. 5, at p. 196 (questioning, rightly, to what extent norms originally designed to govern the conduct of public actors can be transplanted into the private sphere).

124. Or a state must have violated one of its own obligations in relation to the regulation or supervision of TNC conduct. See n. 29 supra and accompanying text.

125. Or, put differently, obligations that states owe to such actors.

126. Reparations for Injuries Suffered in the Service of the United Nations, Advisory Opinion, ICJ Rep. (1949) p. 174.

127. See nn. 15-21, and 68-73 supra and accompanying text. 
business entities could have rights directly under international law, except for those that are provided through specific treaty regimes, such as investment treaties. ${ }^{128}$

\subsubsection{Collective or community concerns}

The range of rules of customary international law that express community concerns with erga omnes effect remains limited and uncertain, especially outside of the above-mentioned human rights context. Reference was made in section 2.1 to the example of global environmental concerns. It was noted that, in this context, the conceptual framework of international law is developing through the evolution of the notions such as common area, common heritage and common concern. The impact of this evolution, however, has been felt not so much in the emergence and application of customary law as in the development of treaty-based regimes. ${ }^{129}$ These regimes serve to enshrine the three concepts in relation to specific areas or concerns, such as Antarctica in the case of the concept of common area, ${ }^{130}$ the deep sea bed in the case of the concept of common heritage, ${ }^{131}$ or climate change or biodiversity in the case of the concept of common concern. ${ }^{132}$ They also flesh out the concepts in the sense that they clarify their legal implications and outline specific commitments of states. In turn, the concepts frame the regimes and help shape their evolution and implementation. In other words, even without customary law status, community interest concepts can be influential in a number of concrete ways. Seen through the lens of the law of state responsibility, the most significant aspect of their treaty-based development is their transformation from emerging erga omnes obligations into norms that frame obligations erga omnes partes. ${ }^{133}$ As such, they do provide a firm foundation for recourse to the law of state responsibility. ${ }^{134}$ Whether or not states will pursue this option is another matter. ${ }^{135}$

128. See e.g., J.J. Coe Jr., 'Taking Stock of NAFTA Chapter 11 in its Tenth Year: An Interim Sketch of Selected Themes, Issues and Methods', 36 Vanderbilt JTL (2003) p. 1381.

129. Of course, over time, developments at the treaty level may give rise to the emergence of new customary law.

130. See Antarctic Treaty, 402 UNTS (1959) p. 71; and Protocol to the Antarctic Treaty on Environmental Protection, reprinted in $30 \operatorname{ILM}(1991)$ p. 1461.

131. See Art. 136 of the UN Convention on the Law of the Sea, reprinted in 21 ILM (1982) p. 1261.

132. See the preambles of, respectively, the United Nations Framework Convention on Climate Change, reprinted in 31 ILM (1992) p. 851; and the Convention on Biological Diversity, reprinted in $31 \operatorname{ILM}(1992)$ p. 818.

133. On the distinction between collective and community obligations see Art. 42(b) of the ILC Draft Articles, supra n. 11. And see nn. 42-54 supra and accompanying text.

134. See generally J. Peel, 'New State Responsibility Rules and Compliance with Multilateral Environmental Obligations: Some Case Studies of How the New Rules Might Apply in the International Environmental Context', 10 Review of European Community and International Environment Law (2001) p. 82.

135. See introduction to Part 3 above. 


\subsubsection{Norm texture}

The international environmental law examples provided in section 2.1 of this article serve to illustrate the fact that many customary rules of international law are too open-textured to facilitate recourse to the law of state responsibility. Customary law, however, tells only part of normative story. Indeed, one might say that customary law furnishes some of the basic normative strands of international law, around which much denser fabric has come to be woven through treaties and a various forms of soft normativity. For example, much as occurred in the abovementioned example of agreements that developed around collective environmental concerns, treaty-regimes have been negotiated to specify levels of permissible environmental harm and provide detailed requirements for emission reductions or regulatory measures. ${ }^{136}$ Detailed standards can also be articulated in legally soft form. Indeed, it is increasingly common for the bulk of technical or regulatory detail in a given treaty regime to be adopted and adjusted not through formal agreement or amendments, but through non-binding decisions under the auspices of the treaty body. ${ }^{137}$ Alternatively, codes of conduct may permit agreement on far more detailed standards than could be achieved through a treaty. ${ }^{138}$ Precisely because they do not purport to be positive international law, such codes can also be employed to shape the conduct of non-state actors, such as the abovementioned TNCs. ${ }^{139}$

These developments, whether binding treaty law or soft law, are nonetheless unlikely to translate into greater application of the state responsibility regime. In the case of soft standards, the reason is obvious - they do not furnish the type of positive primary rule upon which application of the law of state responsibility is premised. In the case of treaty-based developments, the reasons are found in two interrelated phenomena - the aforementioned reluctance of states to formally invoke breaches of international law and the rise of treaty-based accountability processes, to be discussed further in section 3.2.3 below.

136. See J. Brunnée, 'Toward Effective International Environmental Law -Trends and Developments', in S.A. Kennett, ed., Law and Process in Environmental Management (Calgary, Canadian Institute of Resources Law 1993) p. 217 at pp 222-229.

137. See J. Brunnée, 'Reweaving the Fabric of International Law? Patterns of Consent in Environmental Framework Agreements', in R. Wolfrum et al., eds., The Development of International Law in Treaty-Making? (Berlin, Springer Verlag 2005) p. 101.

138. Brunnée, supra n. 136, at pp. 229-235.

139. See supra section 3.1.1 (at nn. 119-124). 


\subsection{Secondary rules}

The secondary norms of international legal accountability too have undergone a steady process of expansion. Such secondary norms are emerging outside of the law of state responsibility, either aiming to replicate the state responsibility regime for other international actors, as in the case of the ILC's effort to develop articles on the responsibility of international organizations, or establishing distinct modes of accountability. As in the realm of primary norms, hard and soft legal techniques are being employed. The discussion begins with a brief exploration of the move from responsibility to liability regimes in international environmental law, a shift that implicates both primary and secondary norms. It then turns to a range of treatybased and other accountability processes that aim, on the one hand, to enhance the accountability of non-state actors and, on the other hand, to provide them with improved access to international accountability mechanisms. Finally, it canvasses the rise of treaty-based mechanisms that help improve inter-state accountability, especially with respect to collective or community interests.

\subsubsection{From responsibility to liability}

The practical difficulties posed by the fact that the standard against which the wrongfulness of state conduct is measured is generally one of due diligence, combined with states' reluctance to invoke the law of state responsibility in the first place, prompted a progressive shift in emphasis from international responsibility to liability. More specifically, two developments have occurred in this respect, which can be illustrated particularly well in the context international environmental concerns.

The first development was an attempt to sidestep the thorny matter of state responsibility for wrongful acts by elaborating a system of liability for damage caused by lawful but risk-intensive activities. ${ }^{140}$ Thus, in the 1970s, the ILC began to focus on states' 'liability for injurious consequences arising out of acts not prohibited by international law'. ${ }^{141}$ However, it was ultimately unable to get a handle on scope and thrust of the project. ${ }^{142}$ Indeed, from the outset the conceptual under-

140. In comparison to state responsibility, 'international liability refers more generally to mechanisms for compensating and otherwise remedying harm caused by states or other actors, whether or not the harm resulted from the breach of an international obligation." See T.A. Berwick, 'Responsibility and Liability for Environmental Damage: A Roadmap for International Environmental Regimes', 10 Georgetown IELR (1998) p. 257, at p. 259.

141. While the topic was cast in general terms, transboundary environmental harm quickly emerged as a central issue. See G. Hafner and H.L. Pearson, 'Environmental Issues in the Work of the ILC', 11 YIEL (2000) p. 3, at p. 23.

142. Ibid., at pp. 23-24. 
pinnings of the topic had been heavily criticized. ${ }^{143}$ The ILC eventually decided to further divide the 'liability' topic into work on the prevention of transboundary harm from hazardous activities, and work on liability for injurious consequences. ${ }^{144}$ The former project resulted in the completion, in 2001, of draft articles that flesh out obligations of states regarding harm prevention. ${ }^{145}$ The prevention articles thus have the potential to help consolidate and tighten the normative texture of the central primary rules of international environmental law. ${ }^{146}$

The second set of developments consists of liability regimes for specific, highrisk activities, such as nuclear power generation or maritime transport of oil. These agreements initiated a shift from state liability to civil liability, aiming to channel liability, and costs, to owners or operators of high-risk undertakings. The agreements typically provide for strict liability of owners or operators, limit their liability to a maximum amount, and require the insurance coverage for that amount. Given that the relevant liability limits may be insufficient to cover all losses, they are supplemented by compensation funds that are financed by state parties or industry sectors. ${ }^{147}$

The shift to civil liability that occurred in issue-specific treaty regimes has now been taken up by the ILC in its effort to complete the second part of its abovementioned liability project. In a March 2003 report, based on a sober review of state practice on loss allocation, the Special Rapporteur for the liability topic had concluded that any further work of the ILC should focus civil liability, rather than state liability. ${ }^{148}$ The ILC consequently turned its attention to consideration of a "model of allocation of loss" that would be 'both general and residuary'. ${ }^{149}$ In 2004, the ILC adopted a set of 'Draft Principles on the Allocation of Loss in the case of Transboundary Harm arising out of Hazardous Activities'. ${ }^{150}$ Whether or not this attempt to develop a global civil liability regime for transboundary harm

143. See e.g., A. Boyle, 'State Responsibility and Liability for Injurious Consequences of Acts not Prohibited by International Law: A Necessary Distinction?', 39 ICLQ (1990) p. 1.

144. See P.S. Rao, First report on the legal regime for allocation of loss in case of transboundary harm arising out of hazardous activities, UN Doc. A/CN.4/531 (21 March 2003) at para. 33 .

145. The UN General Assembly took note of the articles, and asked the ILC to proceed with its work on liability. See Rao, ibid., at para. 36.

146. See supra sections 2.1 and 3.1.3.

147. See J. Brunnée, 'Of Sense and Sensibility: Reflections on International Liability Regimes as Tools for Environmental Protection', 53 ICLQ (2004) p. 351, at pp. 356-358. Over the last decade or so, there has also been a marked trend towards including liability issues in the agenda of MEA negotiations. See ibid., at pp. 358-364.

148. Rao, supra n. 144 , at para. 114.

149. Ibid., at para. 152 .

150. See ILC, Report of the International Law Commission on the Work of Its Fifty-sixth Session, UN GAOR A/59/10, at paras. 158-176. 
will be more attractive to states than the state liability project remains to be seen. Also awaiting resolution are complicated questions concerning the relationship between civil liability and state responsibility in a given case. ${ }^{151}$

\subsubsection{Non-state actors}

\subsubsection{Accountability of non-state actors}

The shift towards civil liability in the environmental field discussed in the previous section is of course salient as one of the manifold initiatives that aim to channel accountability to actors other than states. However, in the liability realm, the role of international law has been more one of setting the parameters for civil liability regimes to be implemented by states than one of establishing direct international legal accountability of non-state actors.

The most significant form of such direct accountability has without doubt emerged with respect to individuals and in the field of international criminal law. While by no means a perfect analogy, it is fair to say that, in addition to the primary rules that outline individual crimes, international criminal law today includes certain secondary rules on the responsibility of individuals for such crimes. ${ }^{152}$ It is also in this area that the most elaborate legal accountability processes are found. A number of ad hoc criminal tribunals as well as, most recently, the permanent International Criminal Court, enable the prosecution of atrocities at the international level. ${ }^{153}$

A distinct system of accountability is also emerging for international organizations. The work of the ILC is focused only upon 'breaches of obligations that are imposed on international organizations by international law' ${ }^{154}$ It is modeled upon the Commission's work on state responsibility but extends to additional questions raised specifically by the application of the concept of responsibility to international organizations. For example, difficult questions of attribution can arise, including the question when a given breach of international law should be treated as a matter of state rather than organizational responsibility. ${ }^{155}$ Other complexities with which the ILC has grappled in its work to date are raised by the question

151. See Boyle, supra n. 27, at pp. 23-25.

152. See e.g., Arts. 22-33 of the Rome Statute of the International Criminal Court, reprinted in $37 \operatorname{ILM}(1998)$ p. 999.

153. See C. Blakesley, 'Atrocity and its Prosecution: The Ad Hoc Tribunals for the Former Yugoslavia and Rwanda', in T. McCormack and G. Simpson, eds., Law of War Crimes: National and International Approaches (The Hague, Kluwer Law International 1997) p. 189; W.A. Schabas, An Introduction to the International Criminal Court (Cambridge, Cambridge University Press 2004).

154. Gaja, supra n. 112, at p. 6 (para. 16).

155. Ibid., at pp. 10-19. 
whether and to what extent responsibility extends to violations of the internal rules of an international organization. ${ }^{156}$ The ILA project on accountability of international organizations sidesteps some of these difficulties by casting its normative net more widely to include general rules of international law, internal rules and soft standards. ${ }^{157}$ In keeping with this wider normative frame of reference, the ILA's concept of accountability is considerably broader than the ILC's concept of legal responsibility. It is based on a general duty to account for the exercise of power, be it legal, political, administrative or financial, ${ }^{158}$ and extends to "all component entities of the international community, provided their interests or rights have been affected". ${ }^{159}$ As far as the procedural dimensions of accountability of international organizations are concerned, implementation through binding international processes is certainly feasible. ${ }^{160}$ However, for the time being, the most extensive international accountability practice is grounded in soft law processes: institutions such as the World Bank and various regional development banks provide for a range of relatively informal and non-legally binding assessment or inspection mechanisms. ${ }^{161}$

No comparable secondary rule development has as yet taken place with respect to transnational corporations. That a gap remains in this respect should be not be surprising. After all, unlike individuals and international organizations, respectively, TNCs are neither recognized as possessing international legal personality nor, as a result, have positive primary norms emerged to govern their conduct. For the moment, therefore, efforts to hold TNCs and other business entities to certain human rights, environmental or labour standards rely primarily on soft accountability processes, such as the publicization of corporate misconduct by non-governmental groups ${ }^{162}$ or on various voluntary reporting and assessment initiatives undertaken by TNCs themselves. ${ }^{163}$

156. Ibid., at pp. 7-9.

157. See supra section 3.1.1 (at nn. 113-114).

158. See ILA, supra n. 2, at p. 168.

159. Ibid., at p. 169.

160. Ibid., at pp. 226-234 (referring to international administrative tribunals, arbitral tribunals and, potentially, the ICJ at the international level, and domestic courts at the national levels).

161. For a detailed analysis see D.D. Bradlow, 'Private Complaints and International Organizations: A Comparative Study of the Independent Inspection Mechanisms in International Financial Institutions', 36 Georgetown JIL (2005) p. 403.

162. See e.g. D. Shelton, 'Protecting Human Rights in a Globalized World', 25 Boston College I \& Comp. LR (2002) p. 273.

163. See e.g., the UN Global Compact, $<$ http://www.unglobalcompact.org $>$. And see generally D. Cassel, 'Corporate Initiatives: A Second Human Rights Revolution?', 19 Fordham ILJ (1996) p. 1963. 


\subsubsection{Accountability to Non-State Actors}

Relatively more progress has been made in enabling non-state actors to hold other international actors, primarily states, accountable for violations of their international rights. For example, an ever-growing range of bilateral and multilateral agreements enables business entities to proceed against state parties to settle investment disputes. ${ }^{164}$ Under a side agreement to the North American Free Trade Agreement, individuals or non-governmental organizations can petition a trilateral commission with complaints about a state party's failure 'to effectively enforce its environmental law' ${ }^{165}$ Most notably, however, a number of human rights treaties enable individuals to complain about violations of their treaty-based rights by state parties. ${ }^{166}$ One of the most extensive and active systems has evolved under the European Convention for the Protection of Human Rights and Fundamental Freedoms, ${ }^{167}$ where individuals have recourse to the European Court of Human Rights, which in turn can render decisions that bind state parties. A more common approach is that provided for under the International Covenant of Civil and Political Rights (ICCPR) ${ }^{168}$ In this regime, state parties can choose to join an Optional Protocol that entitles individuals to petition the UN Human Rights Committee with complaints about violations of their Covenant Rights. ${ }^{169}$ Aside from the fact that states must agree to subject themselves to this accountability mechanism, ${ }^{170}$ the 'views' that the Committee issues upon its consideration of the complaint are not legally binding upon the state concerned. Nonetheless, once a state is subject to the system, a degree of accountability is generated by publicly measuring the state party's conduct against the international standard, and by the attendant pressure on it to comply. ${ }^{171}$ The Human Rights Committee too has developed an extensive accountability practice, issuing around 120 'views' on individual cases every year. ${ }^{172}$

164. See J. Collier and V. Lowe, The Settlement of Disputes in International Law: Institutions and Procedures (Oxford, Oxford University Press 1999) at pp. 59-73; Coe, supra n. 128.

165. See Art. 14 of the North American Agreement on Environmental Cooperation, reprinted in 32 ILM (1993) 1480. And see C. Tollefson, 'Games without Frontiers: Investor Claims and Citizen Submissions under the NAFTA Regime', 27 Yale JIL (2002) p. 141.

166. See e.g., Brown Weiss, supra n. 53, at pp. 809-811.

167. European Convention for the Protection of Human Rights and Fundamental Freedoms, $213 \operatorname{UNTS}(1950)$ p. 222.

168. International Covenant on Civil and Political Rights, 999 UNTS (1966) p. 171 [hereinafter ICCPR].

169. See Optional Protocol to the ICCPR, 999 UNTS (1966) p. 302.

170. As at 26 January 2006, 105 of the 155 parties to the ICCPR had done so. See $<$ http:// www.ohchr.org/english/countries/ratification/5.htm> .

171. According to Kindred et al., supra n. 116, at p. 909 the 'record of state compliance with [Committee] decisions ... has been variable, with a small number of states systematically ignoring the conclusions of the Committee, and the majority making good-faith efforts to implement'.

172. Ibid. 


\subsubsection{Inter-state accountability}

As previously noted, even when the interests of individual states or their collective interests are affected, states only rarely hold one another accountable on the basis of the state responsibility regime. Instead, they have developed a range of alternative strategies, anchored in issue-specific treaty regimes and tailored to the concern at hand.

A variety of treaty regimes provide for specific dispute settlement mechanisms to address disagreements on rights and obligations under the treaty. The spectrum runs from formal judicial forums, such as the International Court of Justice or the International Tribunal on the Law of the Sea, to quasi-judicial processes, such as the World Trade Organization's dispute settlement procedure. ${ }^{173}$ Indeed, the range of options has grown to the point that concerns have been voiced over the proliferation of international tribunals with overlapping spheres of jurisdiction. ${ }^{174} \mathrm{Be}$ that as it may, while recourse to these formal inter-state mechanisms is relatively common in some areas, such as international trade law, it remains the exception in others, such as human rights or environmental law.

In these latter areas, states have preferred to avail themselves of a menu of other options. Both human rights and environmental agreements tend to rely on extensive reporting requirements. The reported information enhances accountability, transparency and trust as to parties' performance, an effect that is reinforced by the publication of the reports among parties, or even their release to the general public. In many treaties today, reporting serves a second crucial function by providing the foundation for compliance assessment processes within the regime. ${ }^{175}$

It is important to appreciate that these compliance mechanisms are embedded in larger regime-driven dynamics. For example, multilateral environmental agreements enmesh states in increasingly dense interactions and collective deliberation, justification and judgment. They legitimate continuous processes of norm setting and facilitate the input of a wide range of actors. While states remain the primary decision-makers, a number of channels exist for non-governmental organizations, busi-

173. See R.O. Keohane et al., 'Legalized Dispute Resolution: Interstate and Transnational', in J.L. Goldstein, et al., eds., Legalization and World Politics (Cambridge MA, MIT Press 2001) p. 73.

174. See e.g., B.Kingsbury, 'Foreword: Is the Proliferation of International Courts and Tribunals a Systemic Problem?', 31 NY Univ. JIL \& Pol. (1999) p. 679; P.M. Dupuy, 'The Danger of Fragmentation or Unification of the International Legal System and the International Court of Justice', 31 NY Univ. JIL \& Pol. (1999) p. 791.

175. For a detailed review in the environmental context, see K. Raustiala, Reporting and Review Institutions in 10 Multilateral Environmental Agreements (UNEP 2001) at p. 11; $<$ www.unep.org/GEO/techreports.htm>. 
ness groups and expert networks to feed into these rolling regulatory processes. ${ }^{176}$ In this manner, the agreements foster the growth of dynamic interpretative communities. In addition, in promoting continuous information gathering, they facilitate the adaptation of standards and commitments. Arguably, through these features treaty regimes provide unique opportunities for realizing the concept of legal accountability that was set out at the beginning of this article. Thus, treaty regimes appear to be well suited to fostering the emergence of shared normative understandings and the elaboration of rules that are compatible with one another, that are seen to place reasonable demands on participants, that are transparent and relatively predictable, and that actually guide decision-making and rigorous compliance assessment processes. ${ }^{177}$

It is through regime-specific peer review processes or 'non-compliance procedures', which have emerged over the last 15 years or so, that justification and judgment can be contextualized and tied into ongoing regime development. All of the existing compliance procedures place heavy emphasis on such 'justificatory discourse'. ${ }^{178}$ Once a compliance procedure has been triggered, the party in question must provide information on and explain its performance through written and oral exchanges with the compliance body. ${ }^{179}$ In some cases, this justificatory dynamic is intensified by calling on parties with compliance difficulties to develop compliance action plans and by providing for the review of their implementation. ${ }^{180}$

In the human rights field, where compliance with treaty commitments and implementation through various governmental measures are closely connected, implementation review is the main accountability technique. For example, under the ICCPR, parties must report on legislative, judicial and administrative measures adopted to implement the convention. The Human Rights Committee will then engage individual parties in 'constructive dialogue' regarding their performance. ${ }^{181}$ This implementation review process, which is distinct from the individual complaints process mentioned in the previous section, serves similar functions as compliance assessments and proceeds in comparable fashion. However, it does not make explicit determinations regarding a party's compliance with treaty commit-

176. See S. Charnovitz, 'Two Centuries of Participation: NGOs and International Governance', 18 Michigan JIL (1997) p. 183.

177. See Brunnée, supra n. 137, pp. 118-123.

178. See J. Brunnée, 'Enforcement Mechanisms in International Law and International Environmental Law', Xvol.X Environmental Law Network International Review (2005) p. 3, at p. 10. The term 'justificatory discourse' is drawn from A. Chayes and A. Handler Chayes, The New Sovereignty: Compliance with International Regulatory Agreements (Cambridge MA, Harvard University Press 1995) at p. 26.

179. See Brunnée, ibid., at p. 11.

180. Ibid.

181. See ICCPR, 'Overview of the working methods of the Human Rights Committee', para. $\mathrm{V} ;<$ http://www.ohchr.org/english/bodies/hrc/workingmethods.htm>. 
ments. Rather, the dialogue with a party about its report leads to 'concluding observations', in which the Human Rights Committee highlights positive aspects of the party's implementation efforts, flags subjects of concerns, and offers recommendations for improved performance. ${ }^{182}$

The potential significance of 'concluding observations' concerning implementation problems or determinations of non-compliance should not be underestimated. Indeed, it would be worth exploring whether, in their impact on state conduct, the outcomes of treaty-based performance review processes differ significantly from the formal findings of 'breach' that a state responsibility assessment might yield. Whatever the case may be, treaty-based accountability processes employ a far more nuanced set of responses to non-compliance than can the state responsibility regime, premised as it is upon wrongfulness.

For example, findings of non-compliance and recommendations for improved performance alone are unlikely to bring a party into compliance where capacity limitations are at the root of its failure. Nor would the secondary obligations triggered by the law of state responsibility, or countermeasures by an injured state, be likely to induce compliance. Various forms of advice and assistance are therefore among the possible outcomes of treaty-based compliance processes in both the environmental and human rights areas. ${ }^{183}$ Conversely, facilitative approaches alone may not suffice to induce compliance where strong countervailing interests are at play. Environmental agreements, for example, can engage significant financial and competitiveness considerations. In such cases, enforcement-oriented outcomes may be required, both to induce a party's compliance and to assure other parties of a level playing field. Accordingly, notwithstanding their emphasis on facilitation and cooperation, most environmental regimes do have enforcement-oriented features, at least in the wider sense of creation of costs or removal of benefits. ${ }^{184}$ As already noted, compliance regimes usually allow for the publication of parties' compliance records; some permit the issuance of 'cautions' to non-complying parties. ${ }^{185}$ Some compliance regimes also envisage the suspension of certain 'privileges' under the agreement (such as access to funds) when a party fails to meet its commitments. Finally, while rare, under some environmental agreements, non-compliance may result in trade restrictions, or in other hard-edged consequences. ${ }^{186}$

182. See ICCPR, ibid.

183. For example, the compliance procedure under the Montreal Protocol on Ozone Depletion neatly encapsulates this approach in stating that it is aimed at 'securing an amicable solution ... on the basis of respect for the provisions of the Protocol'. See UNEP, Report of the Tenth Meeting of the Parties to the Montreal Protocol on Substances that Deplete the Ozone Layer, Annex II: NonCompliance Procedure, UNEP Doc. OzL.Pro.10/9, 3 December 1998, p. 8.

184. See Brunnée, supra n. 178, at p. 11.

185. Ibid.

186. Ibid. 
One more point is worth making: arguably, none of the outcomes of the compliance control processes surveyed above are formally binding. ${ }^{187}$ Compliance control, it seems, operates on the basis of two contradictory but also mutually reinforcing phenomena. On the one hand, it would seem that the soft law nature of the compliance control enterprise is what makes it acceptable to treaty parties. One can surmise that few, if any, of the abovementioned compliance processes would operate if their outcomes were formally binding. Yet, on the other hand, it also appears that their soft nature does not make them any less effective than binding measures might be. They seem to derive their force from the ongoing interactions in which they are anchored, rather than from formal legal status.

\section{CONCLUSION}

The state responsibility regime is focused upon the accountability of a certain type of international actor, the state, to its peers. The background standard of accountability is a certain type of international norm - rules of positive international law. Within these parameters, the law of state responsibility does address all the elements of the broader definition of international legal accountability set out in the introduction to this article. It allows for states' performance to be assessed. The assessment is of a particular type, leading to determinations of breaches of international law and thus 'wrongfulness' of state conduct. Wrongfulness, in turn, triggers certain legal consequences, including possible compensation of injury suffered by the victim of the wrongful act. Finally, the state responsibility regime provides for limited enforcement options, circumscribing the measures states may take to induce the responsible state to meet its obligations to the victim of the breach.

All of these elements are available, at least in principle, when the accountability issue matches the classical, bilateral paradigm of international law, and involves a violation by one state of the rights of another. However, the more that the accountability issue is removed from this paradigm, the thinner the response provided by the state responsibility regime. One might think of the state responsibility regime as a set of conceptual lenses that progressively filter out more and more accountability elements. The concept of internationally wrongful act, including the rules on attribution, serves to include certain violations of international law in, and exclude others from, the reach of the state responsibility regime. The parameters for the invocation of responsibility further limit the realm of accountability, as they

187. For a detailed discussion, see J. Brunnée, 'Compliance Control Through Active Treaty Management: The Engine that Could?', forthcoming in G. Ulfstein et al., eds., Making Treaties Work - Human Rights, Environment and Arms Control (Cambridge, Cambridge University Press 2006). 
determine for which wrongful acts states can be held to account and by whom. These parameters rest upon the distinction between injured and other states. Where collective or community obligations are violated, only a directly affected state will be injured. While the Draft Articles clarify that all other states may invoke the violation of such collective or community rights, they also enshrine limits to the remedies that such states can claim and to the measures they can take to induce the compliance of the responsible state.

The perhaps most revealing effect of the state responsibility lens is precisely that it provides only a partial view of the rich legal environment in which the interstate strands of international law have come to be embedded. Diverse modes of international accountability have evolved, state responsibility being but one of them.

Some alternative regimes have developed that focus on accountability of nonstate actors. One such development is the shift from state to civil liability regimes for environmental harm. Another type of accountability regime is found in the area of international criminal responsibility of individuals. Distinct regimes are also emerging for the responsibility or accountability of international organizations. One way to read these developments is that they help fill the accountability gaps left by the law of state responsibility and serve to channel accountability to the appropriate actor. However, it is also important to bear in mind the potential downsides of shifting accountability away from states. To the extent that actors other than states genuinely are most 'responsible' for a given breach, the development is a welcome complement to the law of state responsibility. To the extent that states are let 'off the hook' for their share of responsibility, the accountability victory is partial at best. ${ }^{188}$

It is important, therefore, that alternative regimes have also evolved to enhance the chances that states themselves are held accountable in circumstances where the state responsibility regime is unable or unlikely to deliver. A growing variety of treaty-based regimes provides procedural alternatives to the invocation of state responsibility. Treaty-based regimes have assumed particularly important roles in facilitating collective accountability processes. Collectively articulated and validated standards and collective processes legitimate accountability in a way that unilateral defence of common interests rarely can. This legitimacy dimension may help explain why treaty-based accountability processes have become routinized while the invocation of state responsibility has not. It may also help explain why it appears to be of secondary importance whether the underlying standards, or the 'judgments' produced by such processes, are formally binding or not. Either way, treaty-based collective accountability processes appear to generate considerable discursive and social pressure upon non-compliant parties, and appear to enable

188. See also C. Chinkin, 'A Critique of the Public/Private Dimension', 10 EJIL (1999) p. 387. 
the imposition of non-compliance consequences that are tailor-made to the concerns that animate the regime.

Some final reflections are in order. The continuing expansion of the international legal system will be sustainable only if it is matched by a diversification and strengthening of the structure and processes of international legal accountability. The reason is as simple as it is fundamental: accountability is central to the very idea of international legality. The existence of an international legal order presupposes that the conduct of international actors is consistently measured against existing legal standards. The strength of the state responsibility regime is that it automatically applies to internationally wrongful acts and in that sense asserts international legality. Its weakness is that it does not apply to all breaches of international law and, most importantly, that it is so rarely invoked even where it is applicable. It seems safe to predict that the law of state responsibility nonetheless will remain central as a conceptual framework that underpins, backstops and prompts a growing penumbra of complementary approaches. At the same time, while state responsibility may still be the 'paradigm form of responsibility on the international plane', it is not clear that it constitutes the paradigm form of legal accountability in contemporary international practice. To be sure, not all of the alternative modes of accountability that have emerged may amount to legal accountability, even in the wider sense posited here, and the point of this article was not to make that claim. Rather, what this article has sought to illustrate is that the concept of international legal accountability is at once wider and more ambitious than the law of state responsibility and the purely formal conception of international law in which it is rooted.

\section{ABSTRACT}

International legal accountability involves the legal justification of an international actor's performance vis-à-vis others, the assessment or judgment of that performance against international legal standards, and the possible imposition of consequences if the actor fails to live up to applicable legal standards. This article examines questions of accountability in the international legal system through the lens of the state responsibility regime. It begins with an examination of the law of state responsibility and the accountability framework that it provides. By definition, that framework can facilitate only inter-state accountability on the basis of positive legal rules. The article then turns to the increasingly rich variety of other modes of international legal accountability. The rise of these alternative modes reflects the expansion of international law's normative horizons beyond inter-state concerns, the widening of the range of international actors, and the diversification of international law-making and implementation methods. It also reflects the fact 
that states rarely resort to the law of state responsibility to hold one another accountable for breaches of international law. Thus, while state responsibility remains the 'paradigm form of responsibility on the international plane', it is not clear that it constitutes the paradigm form of legal accountability in contemporary international practice. 